\title{
Curriculum Implementation Towards Education 4.0
}

\author{
Randy L. Palestina* \\ a randy.palestina@gmail.com \\ De La Salle Lipa, Lipa City, Batangas, Philippines
}

\begin{abstract}
The challenges of innovating teaching and learning to meet the current demands of $21 \mathrm{st}-$ century lifelong learning is the goal of Education 4.0. Industrial Revolution 4.0 (IR) being characterized as the era of massive development of smart machines, the enormous convergence of information technology, and remarkable platforms for communication and collaboration, becomes one of the significant drivers of Education 4.0. IR 4.0 brings education to raising the bar. Hence, Education 4.0 becomes mandatory to be implemented and integrated into the curriculum. The successful implementation of this integration rests upon the hands of the teachers being considered as the curriculum implementers. Hence, this study aims to explore the understanding of the teachers on education 4.0 and their practices in terms of integrating the concept with the senior high school ABM curriculum. Using a case study, the research was conducted among eight participants in a multi-level private school in the southern part of Manila and found out that the teacher's understanding of education 4.0 was based on two major concepts which include (a) integration of technology into teaching through blended learning, and (b) preparing students to become lifelong learners through integrating transversal competencies and 21st-century learning skills in the curriculum. With the teachers' use of the learning management system, blended learning which integrates the transversal competencies in the curriculum and the development of 21 st-century skills became possible. The practices of the teachers in
\end{abstract}


integrating technology through blended learning in teaching, ensuring the development of the 21st-century skills, and transversal competencies to ensure the implementation of teaching and learning within the concept of education 4.0 are discussed in detail.

Keywords: education 4.0; transversal competencies; 21st-century skills; blended learning; teaching practices; curriculum implementation

\section{INTRODUCTION}

Education 4.0 is now the buzz word in the academe. It is considered as an educational reform that addresses the need of the Industrial Revolution (IR) 4.0. The alignment between the industry, its labor requirements, and the worker's competencies, drives the focus of Education 4.0. The integration of 21st-century skills like life skills, learning skills, and information technology skills provides a framework for the implementation of Education 4.0. When teachers provide an opportunity for the learners to manifest these skills in the accomplishments of academic requirements, then the learning experience of these learners could be considered as manifestations of Education 4.0. Hence, such manifestations enabled the learners to be prepared for the industry requirements. This is the very essence of why educational institutions around the world direct the focus to implement Education 4.0 in the academe.

There have been numerous research conducted focusing on the implementation of Education 4.0 in the school at various levels. For instance, Robandi, Kumiati, and Sari (2018) identified significant factors in the implementation of education 4.0 which include influences on education, challenges to education, and education which is relevant to industrial revolution 4.0. They asserted that the influences on education include early digitalization and computerization, information education, and administration of digital learning, and changes in the paradigm of the student's thinking. In light of educational 
challenges, they identified infrastructures and facilities, limited human resources, and digital technology. They concluded that internet-based education and character education are the two critical elements to make education relevant.

Likewise, Anealka (2018) identified nine trends related to Education 4.0 which include: (1) learning can be taken anytime and anywhere, (2) learning is personalized, (3) learners are provided with choices on how they learn, (4) learners are exposed more to project-based learning, (5) learning through hands-on and field experience, (6) learning through data interpretation, (7) assessments are varied, (8) learners are involved in curriculum planning, and (9) learners are more independent in their learning. He asserted that these nine trends provide the major shift of education to education 4.0. The nine education trends answered the claim of Reddy (2017) that Education 4.0 would enable the students to be equipped with skills for productive employment in their chosen career through a technology-driven curriculum that is tightly aligned with the practical needs of the economy.

Also, the implementation of Education 4.0 could be made possible through the concerted effort of the educational institution and the readiness of the teachers. As suggested by Anealka (2018), teachers must possess the skills for integrating technology in teaching and must know about implementing blended learning. There have been significant findings on the use of blended learning which positively influence the student's engagement and to improve the student's achievement (Kenney \& Newcombe, 2011; Delialioglu, 2011; Briggs, 2014; Kazu \& Dermirkol, 2014; Hein, 2014; Almasaeid, 2014; Carpenter, 2015). Likewise, integration of transversal competencies in the curriculum provides a significant effect on teaching and learning (Silva, 2009; Schleicher, 2012; Amadio, 2013; Pârvo et al, 2014; ERI-Net, 2015; Crasovan, 2016; Tsankov, 2018). While there has been a claim for the significant integration of the transversal competencies in the 
curriculum, there were areas that need to be looked at. For instance, Hidalgo et al. (n.d.) examined educational policies and curriculum frameworks in the Philippines to find out if the transversal skills are embedded in the curriculum. They found out that the noncognitive skills or otherwise referred to as transversal skills are integrated into the curriculum for the last ten years of the curriculum implementation as evidenced by the policy declaration. The same is true of the Enhanced Basic Education Act of 2013. However, they emphasized the importance of strengthening the translation of these policy declarations in terms of teaching strategies, curriculum implementation, applied assessments, and educational programs. Furthermore, they identified curriculum strategies, assessment measures, and approaches as challenges to education. The measurement of the outcomes calls for a more comprehensive assessment procedure so that the extent to which the non-cognitive skills are measured in terms of their application into practice. These are considerations for their recommendation of a coherent framework for integrating noncognitive skills in the over-all education framework.

Crasovan (2016) emphasized that a framework of transversal competencies that a school could use has not yet been formally developed. Therefore, he proposed that teachers look closely at all the competencies being used in the school to check for possible redundancy and overlapping. He identified the need for a framework where transversal competencies are integrated through consultation with all the stakeholders of the school, linking complementary discipline to cover a wide range of competencies, training teachers, and informing students.

Moreover, the integration of 21st-century skills as a manifestation of the implementation of Education 4.0 has also been explored in several kinds of research. Research findings claim that the integration of 21 st-century learning provides benefits to learners. Psychological research has shown that active engagement with learning leads to 
better learning outcomes such as retention, understanding, and active use of knowledge (Perkins, 2006). The integration of the 21st-century competencies would enable the students to perform routine exercises, investigate, debate, take viewpoints, and so on (Philips, 2015). Boholano (2017) emphasized that the 21st-century skills possessed by teachers could influence the development of the skills among the learners. These skills could be enhanced through the exposure of the teachers to the social media and multitude of applications including web 2.0, smart social networking which requires critical thinking skills and the ability to integrate and evaluate real-world scenarios and authentic learning skills.

Howard (2018) conducted the study on integrating 21st-century skills in the curriculum and concluded that education reforms called for 21 st-century education is characterized as radical. Thus, he offered an alternative curricular vision that includes an eccentric, life-affirming understanding to enable the learners to embrace multidimensionality, responsiveness, and responsibility at the heart of the pedagogical relation. He concluded that when education is based on the theoretical construct of life values, learning and creativity is generative, thus, schools must organize learning in ways that enhance well-being sustainably for all. Chu et al. (2016) after assessing the numerous models of integrating $21^{\text {st }}$ century skills in the curriculum conducted worldwide, they identified the limitations as to lacking the well-articulated "means" by which the "ends" could be achieved. Likewise, they emphasized the need for the appropriate coordination from local to international effort of supporting the schools' implementation, reporting of findings and assessment in the conduct of integrating the $21^{\text {st }}$ century skills.

As has been reported in the research, the implementation of Education 4.0 rest on how the teachers are capacitated in terms of their ability to facilitate blended learning, their clear understanding how $21^{\text {st }}$ century skills are developed among the learners, and how 
transversal competencies are integrated in teaching and learning. If this is so, the significant need to study the teacher's understanding of education 4.0 and their practices of integrating the concept on their teaching provided the basis of this case study.

The Purpose of the Study

There is underlying significance to the conduct of this study. For the school, findings would provide bases for the teacher's training and policy development. The conduct of blended learning could be examined to identify the current practices and therefor address the issues and challenges encountered by teachers.

For teachers, the findings of the study would enable them to realize procedures of integrating Education 4.0 being the essential approach to preparing the learners for the $21^{\text {st }}$ century. Informed results would provide teachers with practical procedures of integrating the $21^{\text {st }}$ century skills and the transversal competencies in their lesson facilitation.

Finally, the ultimate recipients of the benefits of this research are the students. As assumed, when the teachers clearly understanding the concept of education 4.0, they would tend to explicitly implement the integration in the curriculum through teaching strategies and activities. The development of the essential $21^{\text {st }}$ century skills and the transversal competencies would be facilitated.

For future researchers, this qualitative study provides insights on developing curriculum based on the concepts of education 4.0. As the findings contribute to the existing knowledge on curriculum designing that is compliant education 4.0, the study could be a means to support further studies to be conducted using quantitative approach. Hence, progressing the research focus on curriculum development and education 4.0. 
Objectives of the Study

This study aims to find out the teacher's understanding of education 4.0 and to explore the practices these teachers are doing in integrating the concept in the curriculum. It seeks to find out answers to the following research questions:

1. How do teachers understand education 4.0 as a concept, and as a current trend in education?

2. How do teachers perceive through their own understanding the process of implementing education 4.0 ?

3. How do teachers implement the curriculum towards education 4.0 ?

The Assumption of the Study

This study assumes that the concept and understanding of the education 4.0 as the basis for the implementation and integration in the curriculum is based on the teacher's own understanding and perceptions. The way the teacher's implement the integration is based on the blended learning these teachers are using in the facilitation of their lesson. Likewise, it is assumed that the teachers are honest in sharing their practices in integrating education 4.0 in the senior high school ABM curriculum.

Conceptual Framework

The variables needed in this research were taken from the underlying theories and principles of curriculum integration, concepts on transversal competencies and $21^{\text {st }}$ century learning skills. The theoretical framework of this is study is based on curriculum integration by Beane (2005). The framework asserts that there are three principles of integration that 
teachers could facilitate. These principles include (a) thematic integration, (b) conceptual integration, and (c) interdisciplinary integration as a curriculum design as the essential basis for this study. The three principles of integration provide the basis for the data collection and data analysis which are significant to answer the research questions. The figure below shows the conceptual framework of study:

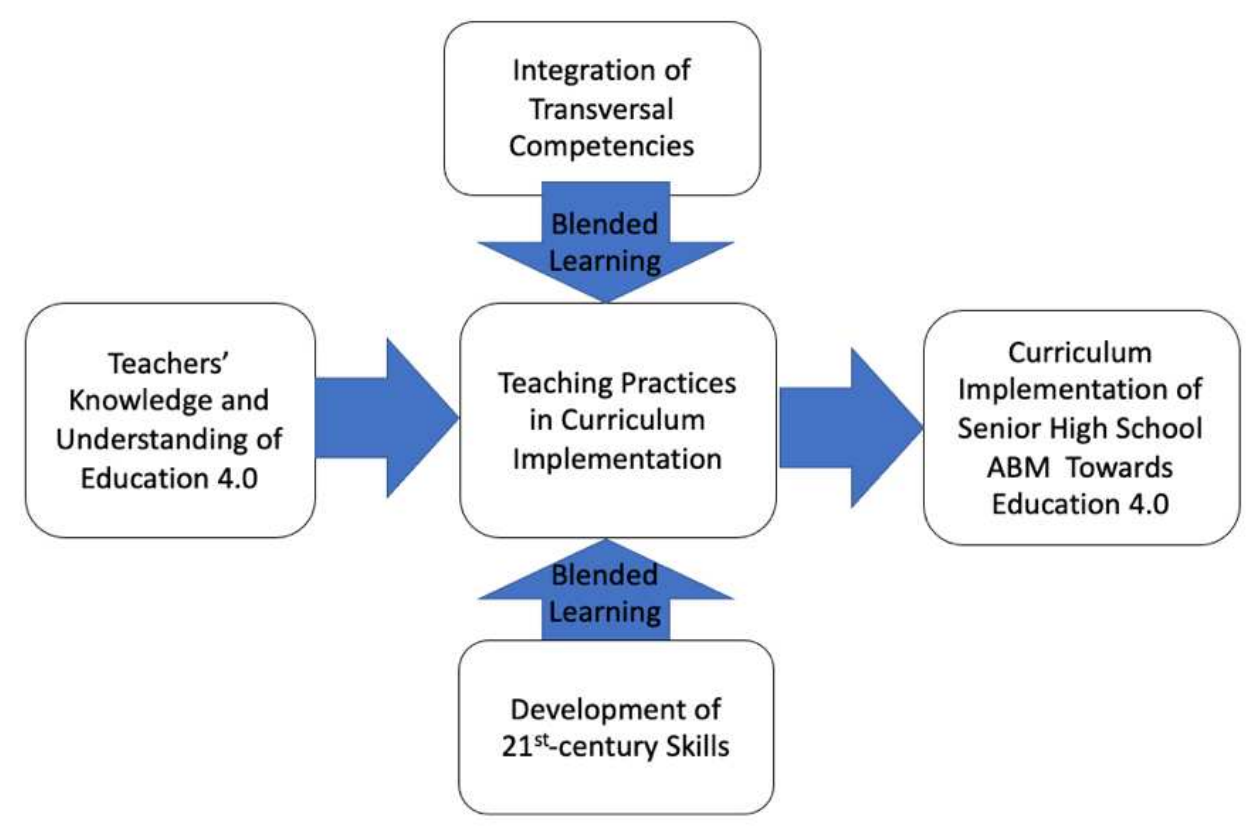

Figure 1

Conceptual Framework

\section{METHODOLOGY}

The study used case study design. As Teegavarapu, Summers and Mocko (2008) argued, case studies are employed for the purpose of analyzing a phenomenon, generating hypotheses or in validating a method. Since the focus of this study is to find out the understanding of the teachers about education 4.0 as well as to explore their practices in 
integrating education 4.0 in the curriculum, case study is the most appropriate design. The study is conducted during the second semester of the school year 2019-2020 in one of the multi-level schools in the southern part of Manila Philippines. Eight teachers were the participants in the study. These participants were chosen using total enumeration as there were only eight teachers who handled courses in the Senior High School ABM Strand during the second semester. Table 1 shows the demography of the participants.

Table 1

Demography of Research Participants

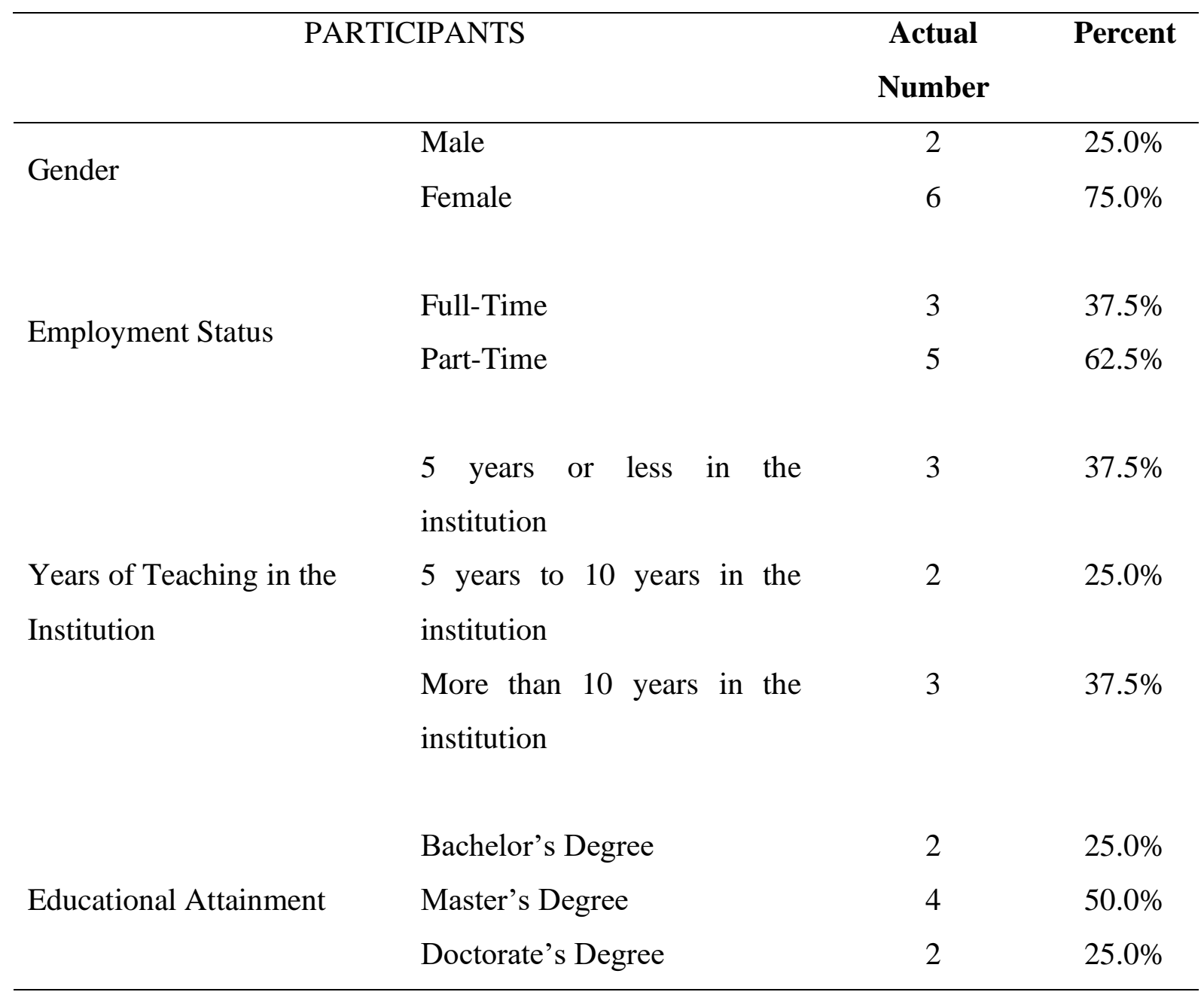


The research used interview and observations as data gathering tools. The interview guide is composed of three parts. The first part is focused on finding out the teacher's profile, the second part is composed of three interview questions that dealt on finding out the teacher's understanding of education 4.0, and the last part of the interview guide was questions pertaining to find out the teacher's perceptions on implementing and integrating education 4.0. The data collected were processed using thematic analysis. The emerging themes and the sub-themes generated from the research were used to directly answer the research questions.

The research procedures used in this research include: (a) asking permission from the principal of the school where the study was conducted, (b) upon approval, the request for conducting research based on the ethical requirements of the school was also facilitated, (c) sending the letter to the participants, requesting for their participation with this research, (d) requesting for the filling out of informed consent form, (e) conducting interviews, (f) transcribing the data, and $(\mathrm{g})$ analyzing the data.

The researcher ensured that research ethics was facilitated during the conduct of this study. The ethical guidelines were followed in the conduct of this research. These were done through: (a) seeking approval of the school's authority of the research initiative, (b) minimizing the risk of harm by preventing physical or psychological distress among the participants, (c) ensuring privacy and anonymity of the participants and their responses, (d) seeking for participants' permission for voice recording and picture taking, (e) giving the participants the right to withdraw from research at any time, and (f) obtaining informed consent by ensuring that participants are informed that they are part of the research study and what the research would ask them to do. 


\section{RESULTS AND DISCUSSION}

The detailed results of the study which are anchored on the three research questions which aimed at finding out the teacher's understanding of the education 4.0 and the practices that teachers implemented in integrating education 4.0 in the Senior High School ABM Curriculum are explained in this section.

RQ\#1 How do teachers understand education 4.0 as a concept, and as a current trend in education?

The teachers understand education 4.0 as a concept of integrating technology in teaching and learning. These teachers believed that technology integration in the curriculum would help to ensure the development of lifelong learners. Likewise, teachers believed that education 4.0 is the response of the academe to the requirements of industrial 4.0. Teachers perceived that through education 4.0, the skills and competencies needed by the future industries would be developed among the learners. Through the integration of technology in teaching, teachers believed that integration of transversal competencies and the $21^{\text {st }}$ century skills are possible. This research finding is aligned with the Reddy (2017) which he reported that Education 4.0 would enable the learners to be equipped with skills for productive employment. Moreover, teachers believed that education 4.0 is an evolution in the teaching and learning process where traditional method of teaching must be modified. They believed that education must be centered to the learners considering that they are only the facilitators of learning.

The teachers, in addition, perceived that education 4.0 is one significant trend in education. Through education 4.0, teachers understand that learners must be provided with options on how they would best learn not only the concepts but also the skills and 
competencies that are developed in the lesson. When learners are provided with learning opportunities through hands-on and field experiences, the teachers shared that such implementation is considered as current trends for education 4.0. Apart from these thoughts, the teacher also believed that when learners are given opportunities to take part in the curriculum planning, then such a case is a manifestation of education 4.0. The current trend of education 4.0 which makes the learners the center of the educative process is identical to the assertion made by Anealka (2018). This is manifested when teachers do away the traditional classroom set up of pouring out knowledge and the learners are just passive participants.

Finally, the teachers perceived that education 4.0 as a framework would enable the educational system to be aligned with the current demands of the society. Through the implementation of different learning theories, integration of technology, making the learners the center of the educative process, and integrating both the transversal competencies and $21^{\text {st }}$ century learning skills, the education 4.0 would be realized.

RQ\#2. How do teachers perceive through their own understanding the process of implementing education 4.0 ?

The teachers perception on their implementation of education 4.0 could be clustered to three themes which include; (a) implementation of the lesson following the requirement of the school's 4 Is which stands for introduction, interaction, integration, and introspection, (b) extensive use of learning management system which manifest the requirements to explicitly apply current trends in blended learning procedures, and (c) implementation of education 4.0 in the teaching learning process including assessments.

The teacher's perception of implementing education 4.0 in the conduct of teaching 
and learning were aligned with how they implement the lesson following the required lesson facilitation. Starting with the lesson introduction, then interaction, integration, and introspection. During the introduction process, the teachers believed that education 4.0 required a sense of creativity and innovation. Creativity in the introduction on the first hand, according to the teachers, is the process by which the content is presented in varied ways. For instance, instead of just using a PowerPoint lesson to present the content, involving the students and finding out their prior knowledge would facilitate a learner centered approach, hence an indication of education 4.0. On the second hand, introducing the lesson through a flipped classroom is another way of implementing education 4.0. In this aspect, contents are being provided to the learners in advance. The learners are given ample time to be familiar with the content of the lesson and during the face-to-face interaction, the teachers facilitate activities to let the learners understand the context of the lesson.

During the interaction phase of the lesson, the teacher implement education 4.0 through the application of varied technology. For instance, when teachers used augmented reality ( $\mathrm{AR}$ ) to enable the learners to be exposed to the context of the lesson as applied in a chosen situation, the process is education 4.0. The teachers also implemented other means of technology application like web-quest and gamification during the lesson interaction. Through these technology applications, the students became aware of the practical applications of the lesson in real life.

In the context of lesson integration, the teachers believed that they implement education 4.0 when they considered that the requirements of the lesson are based on a relevant and real-life situation. Since integration of the content is being required of them to relate to a broader concept, topic or other discipline, the use of current situations and problems in the community as drivers for coming up with performance tasks and projects are indicators of implementing education 4.0 in the curriculum. For instance, the teachers 
mentioned that the business proposal of the students answered the problem of unemployment in the chosen community. Through integration of the concept of the lesson with addressing the issues of the community, the teachers believed that education 4.0 is being implemented.

Moreover, the teachers implement education 4.0 in the last lesson episode which is introspection. Teachers understand that introspection is the process of conducting reflection and valuing of the lesson. Aside from using technology to conduct lesson reflection, the learners are provided an avenue to reflect on their own learning and realized the importance of acquiring and developing the competencies of the lesson. For instance, when the learners are making use of concept mapping as a tool for learning reflection, the use of web applications and social networking sites enabled them to implement the concept of education 4.0. Teachers believed that through the process of learning reflections, the students can develop creativity and critical thinking. These two important skills are the manifestations of the skills that need to be developed in education 4.0.

In addition, the extensive use of the learning management system (LMS) as being the requirement of the institution in the facilitation of the lessons, the implementation of education 4.0 becomes possible. Through the LMS, teachers can facilitate a blended learning models which are very much appropriate in the environment for education 4.0.

Finally, the assessment which measures both the student's learning and the effectiveness of instructions are being done in the context of education 4.0. Teachers used online assessments, performance or outcomes-based assessment, and authentic assessments. These assessment tools are based on the concept of the three major assessment goals which are: (a) assessment of learning, (b) assessment for learning, and (c) assessment as learning. Learners, according to the teachers, were given an opportunity to take part in deciding for 
the criterion to be used in assessing their own learning. Students, when required for collaboration and communication, were being subjected to peer evaluation so that they realized the value of their contribution to the group requirements.

In summary, the use of technology in almost all lesson episodes manifests the teacher's perception of the implementation of education 4.0 in the curriculum. Teachers considered learners as active part in the curriculum planning and implementation. Hence, implementing a learner-centered instruction as a current and innovative way of teaching.

RQ\#3 How do teachers implement the curriculum in accordance to Education 4.0.?

Teachers integrate education 4.0 in the curriculum through integration of transversal competencies, integration of $21^{\text {st }}$ century skills, integrating technology in teaching and learning, and using different models of blended learning to suit the competencies, the lesson introduction, teaching strategies, learning activities and assessments. The discussions that follow are the clear indications of the manifestations of integration.

Teachers integrate transversal competencies. These teachers understand that transversal competencies are those non-cognitive skills that need to be developed in the lesson. Interpersonal skills, critical and innovative thinking, global citizenship, and empathy and self-respect are the transversal competencies integrated by teachers in class. The development of the competencies for these skills are integrated in the curriculum guide which the teachers are using. These competencies are mandated by the institution for implementation in teaching and learning aside from the standard requirements of the department of education for the courses that teachers are implementing. In addition, these competencies are translated in all learning episodes. From the lesson motivation, presentation, application and even in assessments, development of these skills was 
manifested.

Likewise, $21^{\text {st }}$ century skills are integrated in the lesson. These skills are explicitly integrated in the learning module. The learning modules are the teaching guides which the teachers consider implementing. Although there were specific skills that are developed in the learning module, the integration of $21^{\text {st }}$ century skills like life skills, learning skills, and information technology skills were included as part of the classroom observation instrument. Teachers recognized the necessity of integration the $21^{\text {st }}$ century skills as there are looked at during classroom observation. In addition, the $21^{\text {st }}$ century skills are manifested in the learning activities and course requirements. For instance, during the grouping activities students are practicing the skills of communication, creativity, collaboration, and critical thinking. These some of the learning skills that are manifested in the learning activities. The exposure of the students towards the current situations in the community enabled them to practice more of the life skills and at the same time the information technology skills as they use web applications and social networking sites to influence the partner community of their initiative and identified solution to the real-world problems. The teachers mentioned that the students are exposed to the community for them to realize real world problems and propose practical solutions.

In addition, the teachers believed that they integrate education 4.0 in the curriculum using blended learning. Blended learning as understood by the teachers pertains to the combination of online and face to face learning to facilitate instructions. For this purpose, the teachers identified different blended learning models are manifestations of education 4.0. They used station rotation, playlist, self-blended, hybrid, flipped classroom among others. The use of these blended learning models enabled them to develop transversal competencies and $21^{\text {st }}$ century skills. Thus, they believed that through these implementations they can integrate education 4.0 in the curriculum. 


\section{Conclusion}

This paper explores the teacher's understanding of education 4.0. The teacher's understanding of the concept enabled them to realize the importance of implementing education 4.0 in teaching and learning. Thus, enabled them to integrate education 4.0 in the Senior High School ABM curriculum.

The teacher's understanding of education 4.0 as a concept pertains to integrating technology in the teaching and learning process which they believed would enable them to ensure the development of lifelong learners. Likewise, they believed that education 4.0 is the response of the academe to meet the requirements of the IR 4.0. Moreover, the teachers believed that education 4.0 is one of the significant trends in the education where innovations in teaching and learning is facilitated. As a manifestation, they perceived that education 4.0 directs instructions to a more learner-centered and doing away the traditional methods.

Moreover, the teacher's perceived that they are implementing education 4.0 in all learning episodes. Through the integration of technology, they can conduct creative lesson presentation, effective discussion, and relevant learning assessments. With the extensive use of the learning management system, the teachers can facilitate different blended learning models.

Finally, the teachers integrated education 4.0 in the curriculum through integration of transversal competencies and $21^{\text {st }}$ century skills. Although these skills are not explicitly included in the prescribed curriculum, the teachers integrated these skills in the 
development of the curriculum guide and translated in the learning module because they believed that these skills should be necessarily developed among the learners. The development of these skills is supported using the different blended learning models which the teachers are using appropriately in the selected topics.

\section{Recommendations}

Findings of this study may be a great consideration for the development and formulation of school policies towards implementation of education 4.0 in the academe. If the integration could be done through the formulation of curriculum guide and learning modules where transversal competencies and $21^{\text {st }}$ century skills are being integrated, it is recommended that other aspects in the teaching and learning process be looked at so that implementation of education 4.0 could be better assessed. Likewise, the curriculum intent on a division and district scale be assessed so that implementation of education 4.0 may find its place through orders and policies so that the approach would be institutional and not sporadic. Moreover, the study provides additional inputs to the body of knowledge as these findings might be corroborated by other research in curriculum, instructions, and pedagogy.

\section{REFERENCES}

Almasaeid, T. F. (2014). The effect of using blended learning strategy on achievement and attitudes in teaching science among $9^{\text {th }}$ grade students. European Scientific Journal, $10(31)$ Retrieved from http://search.proquest.com/docview/1652452544? accountid=28547

Amadio, M. (2013). A rapid assessment of curricula for general education focusing on cross-curricular themes and generic competencies or skills. Paper commissioned for the EFA Global Monitoring Report. Teacher and Learning achieving quality for all.

Anealka, A. H. (2018). Education 4.0 made simple: Ideas for teaching. International Journal of Education \& Literacy Studies, 6(3), 92-98. doi:http://dx.doi.org/10.7575/aiac.ijels.v.6n.3p.92 
Boholano, H. (2017). Smart social networking:21 $1^{\text {st }}$ century teaching and learning skills. Research in Pedagogy. 7(1), 21-29. Retrieved from https://files.eric.ed.gov/fulltext/EJ1149146.pdf

Briggs, K. C. (2014). Blended learning vs. face-to-face instruction: A quantitative evaluation of student achievement in algebra I (Order No. 3665460). Available from ProQuest Dissertations \& Theses A\&I; ProQuest Dissertations \& Theses Global. (1640913684). Retrieved from http://search.proquest.com/docview/1640913684? accountid=285

Carpenter, A. K. (2015). Blended learning and traditional instructional models in a middle school: A causalcomparative study (Order No. 3728989). Available from ProQuest Dissertations \& Theses A\&I; ProQuest Dissertations \& Theses Global. (1746623312). Retrieved from http://search.proquest.com/docview/1746623312? accountid=28547

Chu, S., Reynolds, R., Notari, M., Taveres, N., \& Lee, C. (2016). 21st Century Skills Development through Inquiry Based Learning From Theory to Practice. Springer Science.doi:10.1007/978-981-10-24818.2

Crasovan, M. (2016). Transversal Competences of how to learn differently. Philosophy, Communication, Media Sciences. 171-178. DOI:10.22618/TP.PCMS.20164.349016. Retrieved from https://triventpublishing.eu/books/philosophy/ communicationtoday/17.\%20Mariana\%20Crasovan.pdf

Delialioğlu, Ö. (2011). Student Engagement in Blended Learning Environments with Lecture-Based and Problem-Based Instructional Approaches. Educational Technology \& Society, 15 (3), 310-322.

Hein, J. O. (2014). A comparison of a blended learning environment and a traditional learning environment. are student achievement and student interest affected?(Order No. 3602484). Available from ProQuest Dissertations \& Theses A\&I; ProQuest Dissertations \& Theses Global. (1468689409). Retrieved from http://search.proquest.com/docview/1468689409?accountid=28547

Hidalgo, F., Orencia, M., Papango, M., Reyes, W., Ruscoe, R. (n.d.) Integrating transversal competencies in education policy and practice in the Philippines. COUNTRY CASE STUDY. Philippine Normal University \& Foundation for Upgrading the Standard of Education.

Howard, P. (2018). Twenty-first century learning as a radical re-thinking of education in the service of life. Education Sciences. 8(189), 1-13. Doi:10.3390/educsci8040189.

Kazu, I., \& Demirkol, M. (2014). Effect of blended learning environment model in high school students' academic achievement. The Turkish Journal of $\quad$ Educational Technology, 13,1.

Kenney, J. \& Newcombe, E. (2011). Adopting a blended learning approach: challenges encountered and lessons learned in an action research study. West chest University of Pennsylvania. Retrieved from $\quad$ files.eric.ed.gov/fulltext/EJ918218.pdf.

Pârvo, I., Ipate, D. M., \& Mitran, P. C. (2014). IDENTIFICATION OF EMPLOYABILITY SKILLS STARTING POINT FOR THE CURRICULUM DESIGN PROCESS.Economics, Management and Financial Markets, 9(1), 237-246. $\quad$ Retrieved from https://search.proquest.com/docview/1520014389?accountid=28547 
Perkins, D. (2006). Constructivism and troublesome knowledge Overcoming barriers to student understanding: Threshold concepts and troublesome knowledge, 33-47.

Philips, D. (2015). The good, the bad, and the ugly. the many faces of constructivism. Educational Researcher, 5-12.

Reddy, L. (2017). Envisioning education 4.0. Industry Week, Retrieved from https://search.proquest.com/docview/1943528862?accountid=28547

Robandi, B., Kurniati, E., \& Sari, R. (2018). Pedagogy in the era of industrial revolution 4.0. Advances in Social Science, Education and Humanities Research. 1 (239), 38-46. Retrieved from http://creativecommons.org/licenses/by-nc/4.0

Schleicher, A. (ed). 2012. Preparing teachers and developing school leaders for the 21st century: Lessons from around the world. Paris, OECD Publishing. http://www.oecd.org/site/eduistp2012/49850576.pdf

Silva, E. (2009). Measuring skills for 21st-century learning. The Phi Delta Kappan, Vol. 90, No. 9, pp. 63034. Retrieved from: http://www.jstor.org/stable/27652741

Teegavarapu, S., Summers, J., \& Mocko, G. (2008). Case study method for design research: a justification. DOI: 10.1115/DETC2008-49980 Retrieved from https://www.researchgate.net/publication/238621009

Tsankov, N. (2018). THE TRANSVERSAL COMPETENCE FOR PROBLEM-SOLVING IN COGNITIVE LEARNING. International Journal of Cognitive Research in Science, Engineering and Education, 6(3), 67-82. doi:http://dx.doi.org/10.5937/ijcrsee1803067 